\title{
Towards Effective Transnational Labor Solidarity between NAFTA North and NAFTA South
}

\author{
JOHN D. FRENCH
}

U.S. political scientist Dale Hathaway's article originated in his decision in the mid1990s to tackle the internationalist tasks integral to radical politics in the post-NAFTA (North American Free Trade Agreement) era. Like his book Allies across the Border (2000), it breathes a spirit of militancy and heart-felt commitment to the struggles of working and middle class peoples in today's world. As befits the new Labor History's forum format, the piece eschews cautiously balanced judgments anchored in an impregnable structure of academic argument. Instead, Hathaway offers bold if schematic political reflections about a pressing issue of general importance-the unionization of "runaway" shops in Mexico-and a straightforward partisan advocacy for one voice, the Frente Auténtico del Trabajo (FAT), within Mexico's massive and heterogeneous labor movement.

Refusing to dress up his arguments "as objective social science," Hathaway begins with an avowal of his political objective: "to advance the political fortunes of workers facing a system heavily weighted against them." This is followed, he says, by a "resolutely objective effort to determine how to advance" the goal of achieving "authentic unions in the maquila." To do so, he believes, there is much to be gained from the experience of the FAT, an independent leftist confederation of unions, cooperatives, and related social movements that first came to prominence in the early 1990 s as part of the search for a Mexican labor voice that would join U.S. and Canadian unions in opposing the NAFTA trade agreement. ${ }^{1}$ In 1991 , the FAT joined in a strategic alliance with the United Electrical Workers (UE), a leftist non-AFL-CIO union in the U.S. that found in the FAT a "political soul-mate."

Hathaway's work brings to the fore the key political challenge that emerged during the NAFTA debate: how do trade union organizations and working people build trinational solidarity in North America across profound differences in socio-economic status, interests, and national history? In these comments, I will use Hathaway's piece to illustrate the dilemmas of one common U.S. leftist way of grappling with what is called "globalization." However well-meaning, I suggest, his approach evades key political difficulties that stem from problems that are recognized by the author but left unresolved in the article itself.

I will restrict myself to four major areas of political disagreement: (1) the idea of authentic unionism as an analytical category; (2) the impoverishing impact of partisan

\footnotetext{
${ }^{1}$ John D. French, Jefferson R. Cowie, and Scott Littlehale, Labor and NAFTA: A Briefing Book (Durham: Duke-UNC Program in Latin American Studies, 1995). Available, along with a similar briefing book on labor and the Common Market of the South (Mercosur), from http://www.duke.edu/web/las/ papers.html.
} 
advocacy on the building of effective institutional solidarity across national boundaries; (3) the need to place workers' consciousness at the forefront of our understanding of the shape of labor's struggles; and (4) the role of national specificities and nationalist reflexes in building true and effective labor solidarity within North America.

\section{LABOR SOLIDARITY AS A POLITICS OF ADJECTIVES}

Aiming for political clarity, Hathaway structures his article around a simple contrast between authentic unions and all others (glossed as "subordinated" unions). This typology is buttressed with additional dichotomies: independent and "officialist" unions; democratic and undemocratic unions; unions with integrity and those that are corrupt; those that serve their members and those that pursue the personal interests of union leaders and bureaucrats. The resulting political analysis is limited, I would suggest, by a politics too heavily dependent upon the awarding of laudatory classificatory adjectives.

From my perspective, such either/or, in/out classifications capture little of the complexity of labor politics in Mexico (or the U.S.), as even Hathaway implicitly admits without elaboration. At his most exact, Hathaway speaks of "unions that authentically represent the interests of their workers and that have the ability to protect those interests" (emphasis added). Needless to say, this conjoined definition fails to account for unions that might represent workers "faithfully" and yet lack the power to achieve those interests (however defined). This point is conceded in passing when Hathaway admits that "relatively more authentic unions" (emphasis added) once existed in some parts of the northern Mexican maquiladora zone. In particular he cites Agapito González, boss (cacique) of an organization in Matamoros, Tamaulipas, that was one of the "early maquiladora unions that best represented workers." Hathaway fails, however, to ponder the conclusions that might be derived from this successful CTM-affiliated union that, although thoroughly subordinated, "officialist," and farfrom-democratic, nonetheless delivered wages and benefits for maquiladora workers far better than those in other northern border cities. ${ }^{2}$

This contradictory reality explains why Hathaway is forced, in passing, to introduce additional adjectives besides "authentic": strong unions, effective unions, and strong democratic unions. Such terms are far less judgmental in nature and can be more easily operationalized in practical terms: in the real world not all effective unions are democratic (and vice versa) and not all collaborationist unions fail to defend (at least some) workers' interests. Having recognized a degree of nuance (at least in the past), Hathaway discounts such possibilities in contemporary Mexico, where, he asserts, most unions are corrupt, "only rarely serve their worker-members," and "over $90 \%$ of total collective labor contracts in Mexico are designed primarily to protect the interests of the employer" (an alleged statistic footnoted to a 1999 publication criticizing Mexican labor relations published with support from the FAT and the AFL-CIO).

Yet by definition labor contracts under capitalism protect employers to one degree or

\footnotetext{
${ }^{2}$ On the comparison between the union in Matamoros and those in other border cities, see Edward J. Williams and John Passé-Smith, The Unionization of the Maquiladora Industry: The Tamaulipan Case in National Context (San Diego: Institute for Regional Studies of the Californias, 1992). There is also a fascinating authorized history of Agapito González's union by Alma Yolanda Guerrero-Miller and Cesar Leonel Ayala, Por Eso: Historia de el Sindicato de Fornaleros y Obreros de Matamoros, Tamaulipas (Matamoros: Centro de Investigacion Multidisciplinaria de Tamaulipas/Sindicato de Jurnaleros y Obreros Industriales de Matamoros (CIMTA/SJOI), 1993).
} 
another and worker interests cannot be expected to always prevail in such negotiations (not to mention that workers, their organizations, and leaders have never been free from materialistic temptations). Hathaway's polemical overstatement, however, suffers from more than rhetorical excess. If true, how are we to understand why many corporations, as he himself reports, are moving away from the border towards "more rural, more southerly, and less unionized parts of Mexico?" As he notes, they do so precisely because they wish to avoid the "generous benefits packages" common in the north while searching for an even more "docile" labor force!"

\section{PARTISANSHIP, REPRESENTATIVENESS, AND THE CONDUCT OF UNION DIPLOMACY IN MEXICO}

In truth, Hathaway's Manichean categories stand for little more than a distinction between "good" unions like the FAT, which he applauds, and those that do not win his favor. When he does attempt to define the FAT's uniqueness, moreover, he tells us that the organization believes in "authentically representing the interests of rank and file workers," favors "profound political change" to achieve its goals, and calls for the building of a "political and social movement" that reaches beyond the formal sector and across national boundaries. As a movement, of course, the FAT is unique in many ways, not the least of which is its origin in the right wing Catholic social action movements of the 1950s. ${ }^{4}$ Yet the principles offered by Hathaway fail to distinguish the FAT from most of Mexico's diverse labor left (whose unions accounted for perhaps $10 \%$ of all union membership in the early 1990s, a marked decline from its peak strength in the 1970s). If judged by rhetoric alone, even the sclerotic labor establishment could agree with at least some of these principles, given its use of "class" rhetoric and continued formal adhesion to a postulated "revolutionary nationalism." Indeed, only the unaffiliated "white" company unions would fall categorically outside of Hathaway's definition.

Faced with such ambiguities, the author opts for an excessively simplistic portrait of the many institutional and political actors at work in a very complex and highly decentralized labor movement marked by multiple competing national confederations, weak national unions, regional antipathies, and complex forms of political insertion and alliance. In weaving his way, he writes in a spirit of parti pris so that the results of even FAT defeats are "surprisingly good" while practices that he criticizes in others are overlooked when practiced by those with whom he sympathizes. ${ }^{5}$

This partisan stance verges on the propagandistic when he fails to discuss the FAT's size or influence in any detail. Although his book notes that it is "relatively small" (like

\footnotetext{
${ }^{3}$ On this point, see David Barkin, "Building Trinational Labor Solidarity in an Era of Free Trade," Latin American Labor News 9 (1993-1994:10).

${ }^{4}$ The story of the FAT is by no means unique in Latin America, where ideological dynamics work themselves out quite differently than in the North Atlantic World. Although conservative in origin, Catholic social action initiatives in the 1950 s contributed to popular struggles in fundamental ways in a number of countries, as well as being transformed by that role in birthing the "Liberation Theology" of the 1970s. On the Guatemalan and Brazilian cases, see Deborah Levenson-Estrada, Trade Unionists against Terror: Guatemala City, 1945-1985 (Chapel Hill: University of North Carolina Press, 1994) and Scott Mainwaring, The Catholic Youth Workers' Movement (fOC) and the Emergence of the Popular Church in Brazil, Working Paper 6 (Notre Dame: Kellog Institute, University of Indiana, 1983).

${ }^{5}$ For one of many example, see Hathaway's discussion of productivity improvements and cooperation with employers at the Sealed Power auto parts plant near Mexico City under contract with STIMACHS, the FAT metalworkers union (Allies, 125-134).
} 
TABLE 1.

\begin{tabular}{lcccc}
\hline & $\begin{array}{c}\text { Rounded-off } \\
\text { union } \\
\text { membership in } \\
\text { the mid-1990s } \\
\text { (millions) }\end{array}$ & $\begin{array}{c}\text { Eembership as a } \\
\text { population, 1996entage of non- } \\
\text { (millions) }\end{array}$ & $\begin{array}{c}\text { Membership as } \\
\text { agricultural labor } \\
\text { force }\end{array}$ & $\begin{array}{c}\text { percentage of } \\
\text { all wage and } \\
\text { salary earners }\end{array}$ \\
\hline Mexico & 93 & 7 & 31 & 43 \\
U.S. & 269 & 16 & 13 & 14 \\
Canada & 30 & 4 & 31 & 37 \\
\hline
\end{tabular}

Source: International Labour Organization, World Labour Report 1997-98. Industrial Relations, Democracy, and Social Stability (Geneva: International Labour Organization, 1997), 259, 235, 237.

its U.S. ally the UE), Mexicanist labor historian Barry Carr has estimated the FAT's national membership at between 40,000 and 50,000 in the early 1990s, including many who were not trade unionists in a formal sense. While enjoying some strength in small and middle-sized enterprises in central Mexico, Carr and Hathaway both report that the FAT had no real strength in large plants or in the northern maquiladora zone. ${ }^{6}$

With the FAT accounting for perhaps $1 \%$ of total Mexican union membership, it is far from rash to suggest that effective maquiladora unionization might be more likely to succeed if it were not based on a frontal attack on labor organizations where millions and not thousands of workers are to be found. Yet it is unthinkable, to Hathaway, that part of the problems faced by the FAT - and other sectors of the independent anti-PRI labor movement - might lie in the strategic outlook of a movement whose activists he rightly admires for their selfless devotion and dedicated persistence in the hard and dangerous struggle for worker rights. If the effective unionization of Mexican maquiladoras depends upon the FAT's success, however, we might as well throw in the towel immediately!

Nor can I agree with Hathaway's attack on the AFL-CIO's current policies in Mexico, which seem, based solely on the information Hathaway provides, to reflect a pragmatic recognition of practical realities. The AFL-CIO's Solidarity Center, he says, "is in favor of democratic unions, but they will work with whoever has the [labor] contracts." Citing a particular case, Hathaway criticizes U.S. labor's representative for entering a plant with a CROC leader during a contested representation election. Mincing no words, Hathaway denounces the CROC unionist as an illegitimate leader whose victory was based on violent gangster tactics. Yet U.S. labor's representative, rather than cutting off all ties with him, simply replies that "he was waiting to see if the CROC union would actually improve conditions for the workers or not."

Whatever the facts in this particular case, Hathaway deems it a betrayal and he demands that the AFL-CIO re-evaluate its "policies that prefer contact with existing but corrupt unions over contacts with more democratic unions that are struggling to emerge." While snidely referring to the fact that "democratically-controlled unions are not that common within the AFL-CIO," Hathaway makes clear that he believes that U.S. labor's diplomacy in Mexico should duplicate his own and the UE's alignment

\footnotetext{
${ }^{6}$ Barry Carr, Labor Internationalism in the Era of NAFTA: Past and Present, Latin American Labor Occasional Paper 14 (Miami: Center for Labor Research and Studies of Florida University, 1995), 23; Dale A. Hathaway, Allies across the Border: Mexico's “Authentic Labor Front” and Global Solidarity (Cambridge: South End Press, 2000), 176, 117.
} 
with opposition elements, despite their limited power and representativeness. Indeed, his most concrete recommendation to advance maquiladora unionization is that the U.S. trade union confederation should give money to the FAT to establish a series of worker education centers in the maquila zone staffed by local people and supported by international assistance.

I am actually far more convinced by the observations about U.S. labor solidarity work in Mexico that he attributes, in his book, to Tim Beaty of the Solidarity Center, formerly the representative in Latin America of Public Services International (an international trade secretariat). Hathaway quotes him as sensibly opposing any acrossthe-board boycott of the mainstream of the Mexican labor movement.

While Beaty admires groups like the FAT, he feels it would be foolish for major unions to have relations only with independent unions, and he thus continues to work with government-affiliated union leaderships. He says the AFL-CIO is seeking to improve the lives of Mexican workers and that to do so it must build ties to workers throughout the country. "The fact is that the CTM and other big unions have contracts for most of the organized workers in the country," and he feels there are decent local unions within the CTM and the CROC and hopes these can be encouraged. ${ }^{7}$

To take such a realist position does not, I should emphasize, deny the problematic nature of the prevailing structures of representation in Mexico or the pro-company sycophancy of far too many trade union leaders in that country. Rather, I fear that Hathaway's absolutist moralism, setting up the conflict as one between "good" and "bad" unions, effectively deflects blame away from the real culprits: successive neoliberal governments in Mexico which have ever more comprehensively perverted the Mexican system of labor regulation and, in particular, exempted the maquila sector de facto from national labor law enforcement. Official toleration for such egregious labor law violations and "sweetheart" protection contracts is far more important in explaining the deteriorated wage levels and working conditions in the maquiladoras than the absence of secret ballot union elections (a sensible reform advocated by Hathaway that would be of greatest help in resolving contested elections between rival unions).

In this regard, I believe that blanket condemnation of the overwhelming majority of Mexican unions, their leaders, and practices is neither accurate nor helpful. To build durable cross-border relations, the more powerful actor must strive to avoid selfrighteousness while recognizing that no mass movement of organized working people is ever reducible to its most retrograde elements. True transnational solidarity demands that we grant Mexican trade unionists the same complement of strengths and weaknesses, mixed motives, and fruitful as well as harmful ambitions that we recognize in our own unions and social movements in NAFTA North. It means an end to political exclusion of the left (such as the FAT), the norm of the AFL-CIO's union diplomacy prior to 1995, as well as a refusal to embrace a policy of interventionism on behalf of the left advocated by Hathaway. Above all, it means the building of people-to-people and movement-to-movement ties that bind together those who stand for worker rights and progressive social change.

\section{HATHAWAY, THE FAT, AND WORKERS' CONSCIOUSNESS}

Hathaway's broadly sympathetic portrayal of the FAT's organizational practice is combined with the observation that "nowhere in Mexico is it difficult to find a majority

${ }^{7}$ Hathaway, Allies, 243-244. 
of maquiladora workers who are ready to complain about their oppressive working conditions and their miserably low wages. Thus organizing opportunities are everywhere." If true, the reader is left to wonder why the FAT and its allies have not made greater progress in winning working class support.

A hard-nosed focus on the "bottom line" of Hathaway's article might lead the reader to conclude that it offers little more than a discouraging narrative of successive defeats and failures. The UE-FAT Alliance originated in U.S. concern about shops that went south of the border, although 10 years later, as Hathaway notes, "the FAT has failed to organize a single runaway UE plant." At one point, he discusses the case of ITAPSA in 1997, which pitted the FAT against strong-arm supporters of a CTM local. In the end, he reports that "only $15 \%$ of the workers dared to vote for the FAT" precisely because they were forced to "declare their choice openly before management, union representatives, and labor board officials." For Hathaway, this defeat underlines the "important historical breakthrough" that occurred in 1994 when "GE [General Electric] kept its word on the secret ballot." Though Hathaway does not say so, in fact the FAT won only $11 \%$ of the 1073 votes cast in the 1994 election. $^{8}$

Should such successive failures surprise us, given the FAT's size and powerlessness? And should those of us who are vitally concerned about worker rights be satisfied by Hathaway's narrative in which losses are to be balanced against our feeling of admiration for plucky organizers working under tough conditions? In today's struggles to build transnational solidarity, is it empowering to relativize such defeats, through an act of will and faith, as simply battles in a larger war that will eventually bring victory to the workers? I believe, in contrast, that we need a broader and more generous vision that would place workers themselves more centrally into such narratives of labor struggle. This would require a far richer and less politicized narrative, and one that would more fully investigate the human dynamics underlying revealing episodes such as the Han Young fight in Tijuana that ended with a FAT victory.

Yet even in the case of Han Young, Hathaway reports that "partisans of authentic unions" were left with an empty victory, because "ties with the FAT eventually broke down" leaving the local union's "solidaristic ties in a shambles." This outcome reflected powerful antagonisms between the national and a local FAT leadership. The FAT's national union STIMACHS saw the victory as providing a local foothold, while the ambitions of local FAT leaders led them to accept a "Trojan horse" in the form of a legal charter that allowed them to organize in any local industry rather than remaining a state affiliate of a national union. In their defense, the ex-FAT leaders mobilized a discourse of regionalist resentment against the national capital by claiming that "they did not want to be controlled by Mexico City, that they did not want to rely on people who flew in on airplanes rather than living amongst them."

Hathaway offers another back-handed recognition of how workers' culture and mixed motivations serve as obstacles to his politically charged project of "authentic" worker mobilization. Rank-and-file workers, he says, need to be educated in order "to overcome their learned deference to abusive employers" and to end the "sense of isolation" that leads them not to break their ties with "existing corrupt unions." At the same time, he also emphasizes the dangers facing even "authentic unions," which, without political consciousness, are likely to fall into despotic leadership patterns and

${ }^{8}$ Jonathan Rosenblum, "GE in Juarez: Union Election Tests NAFTA," Latin American Labor News 10-11 (1994): 11-12. 
serve "simply [as] a vehicle for the advancement of ... [their] own members," thus selling "out the larger movement for the sake of more limited gains."

In his narrative, Hathaway more often achieves melodramatic overstatement ("good versus evil") rather than a detached tone of confident realism and firm conviction. Its mobilizing impact is weakened by the harsh contrast between excessively high expectations and the discouraging outcomes recounted. The resulting text is far more pessimistic than it needs to be if it were less short-sightedly political. We need stories for young fighters that offer mature explanations of why labor struggle is so hard and how real world outcomes reflect those analytical truths. Does the abstract entity we call Mexican "workers" exist? And if so, what do they "want"? What are the interests of this collectivity in all its complexity and variability? And how are these interests articulated? Through what institutions and mechanisms? And finally, how do their leaders negotiate to advance these many and at times conflicting interests? And on what terrains (legal, political, economic)?

\section{NATIONAL SPECIFICITIES, NATIONAL SENSITIVITIES, AND NATIONALIST DIVISIONS}

The powerful if often less-than-emancipatory role of organized labor within the Mexican political system has long puzzled North Atlantic observers. Since the revolutionary era (1910-1940), trade unions have thrived in Mexico and become powerfully entrenched institutions that derive and exercise manifold powers from sources that transcend the direct employer/employee context. Yet for the most part, Mexico's trade unions and its highly politicized sui generis industrial relations system are simply caricatured in derogatory and moralistic terms as corrupt, undemocratic, and statedominated. Far too few have sought to explain how working people's interests are fulfilled, betrayed, and contested through and within their trade union organizations.

A masterful 1996 study by Maria Cook, entitled Organizing Dissent: Unions, the State, and the Democratic Teachers' Movement in Mexico, offers an excellent political and institutional study of the emergence, consolidation, and eventual (partial) victory of a rank-and-file insurgency in Mexico's largest union, the Sindicato National de Trabajadores de la Educación (SNTE), between 1979 and 1989. The SNTE's rise to substantial national power since the 1930 s could easily be seen, she says, as the story of the "formation and consolidation of a classic 'official' union, one that came to support the [Mexican] regime and was overseen by an oligarchic leadership." Yet Cook differs from those who would read this as evidence of "the unequivocal domination of the union by the state." For Cook, state/labor relations in modern Mexico are far better understood as a process of "bargaining and exchange," an "unstable equilibrium" in which internal union cleavages are cross-cut with rivalries for power in the governmental, political, and labor spheres. ${ }^{9}$

Yet in much of U.S. leftist and labor discourse, the complex and untidy reality of Mexican trade unionism continues to be forced into a simple pre-fabricated repertoire of inherited images (Mexican workers as victims, despotic union bosses, state-run unions, the Mexican dictatorship). Unfortunately, such polemical expedients, even

\footnotetext{
${ }^{9}$ Maria Lorena Cook, Organizing Dissent: Unions, the State, and the Democratic Teachers' Movement in Mexico (University Park: Penn State University Press, 1996): 59, 32. See also the fine analytical narrative of Mexican labor relations since the Revolution in Kevin J. Middle brook, The Paradox of Revolution: Labor, the State, and Authoritarianism in Mexico (Baltimore: Johns Hopkins University Press, 1995).
} 
when justified as purely tactical decisions aimed at immediate domestic U.S. effect, take a toll upon and erect barriers against the growth of solidarity between the peoples of NAFTA North (Canada and the U.S.) and NAFTA South (Mexico). As economist David Barkin has argued so eloquently, the pressing need for broader transnational alliances within a post-NAFTA North America requires "objective knowledge of each other's histories, victories, and defeats. It requires a search for an understanding of their diverse social movements, and a mutual respect for their strengths and their failures." 10

If we are to build a common future, trade unionists and progressives in NAFTA North must rigorously examine much of what passes for "solidarity" between workers across the North/South divide. ${ }^{11}$ For example, engaged scholars and labor activists from NAFTA North fail for the most part to even consider how their harsh and categorical condemnations sound to many workers and trade unionists in Mexico. It is not surprising that such perceived slights have often prompted nationalist Mexican responses. Commenting on foreign observers who cavalierly denied the legitimacy of Mexican institutions in toto, Mexican scholars Pablo Pascual Moncayo and Raul Trejo Delarbre responded with measured hostility in a 1993 book on Mexican labor responses to NAFTA. Such U.S. and Canadian attitudes demonstrated, to their minds, "an authoritarian posture that deprecates or undervalues the political and legal institutions of Mexico not on the basis of experience and concrete evidence, but on the basis of prejudices." 12 Such perspectives, they went on, demonstrate "little understanding of the relationship between the state and unions in Mexico, or of the conditions of unionism in our country." While criticizing such foreign views, Moncayo and Delarbre offered no excuses for the undemocratic and excessively statist orientation of Mexican labor relations, although they quite rightly reminded their neighbors that the responsibility to reform and improve the Mexican system lies in Mexican, not U.S. or Canadian, hands. ${ }^{13}$

In Hathaway's version of labor internationalism, Moncayo and Delarbre's nationalist criticisms would be rejected out of hand even if they were not advanced by supporters of NAFTA. Imbued with an older vision that "workers have no country," Hathaway is hostile to nationalism even in Mexico, where, he says, "nationalism has been such an important tool for controlling workers." He advances this observation as part of an attempt to address the FAT's "particular political problem," "especially as [foreign] financial resources are transferred," which leads many to deride the organization "as a

\footnotetext{
${ }^{10}$ Barkin, 3. Barkin's deeply insightful article originated as a vigorous criticism of Dan La Botz's leftist diatribe against the Mexican labor establishment during the NAFTA debate. In many ways, Hathaway's book (also published by South End Press) represents a continuity with Botz's book in both its politics and style of argument. See Dan La Botz, Mask of Democracy: Labor Suppression in Mexico Today (Boston: South End Press International Labor Rights Education and Research Fund (ILRERF), 1992) and his response to Barkin's criticism in "A Defense of Mask of Democracy," Latin American Labor News (1994): 10-11.

${ }^{11}$ For a summary of the conclusions about transnational labor solidarity reached in our 1991-1994 project on labor, free trade, and economic integration, see John D. French,. "Reflejos Nacionalistas en el TLC," Memoria 84 (México DF: Centro de Estudios del Movimento Obrero y Socialista, 1995): 27-31 and "Expectativas de Un Transnacionalismo Sindical," Memorial 85 (México DF: Centro de Estudios del Movimento Obrero y Socialista, 1996): 26-31 (reprinted in issues 12-13 and 14 of Latin American Labour News). In English, see "Labor and NAFTA: Nationalist Reflexes and Transnational Imperatives in North America," in Labour and Globalization: Results and Prospects, ed. Ronald Muck (Liverpool: University of Liverpool Press, in press).

${ }^{12}$ Pablo Pascual Moncayo and Raul Trejo Delarbre, Los Sindicatos Mexicanos Ante el TLC (Mexico: Sindicato Nacional de Trabajadores de la Educacion/Instituto de Estudios para la Transición Democrtática, 1993), 174.

${ }^{13}$ Moncayo and Delarbre, 74, 68-69.
} 
tool of foreign unions who want to prevent jobs from coming to Mexico." Unable to wish it away and yet unsure how to respond, Hathaway is reduced to denouncing such attacks as "manipulative hypocrisy" while noting that it was, nonetheless, "a significant problem" for the FAT. What is missing in Hathaway, however, is any recognition of the powerful historical linkage between Mexican workers' struggle and the culminating moments of nationalist self-assertion in Mexican history such as the 1938 expropriation of foreign oil companies. The Mexican governments's official pretext for the exprorpriation, after all, was the oil company's refusal to obey Mexican labor laws!

\section{CONCLUSION: THE FUTURE OF TRANSNATIONAL SOLIDARITY}

International labor solidarity, Barkin reminds us, "is not something to be lightly dismissed or liberally misused. Fraternal support and collaboration are required among potential allies; [but] without proper channels for respectful discussion and analysis, inherited sentiments of inequality can transform an initial search for a common base of action into a hierarchical pattern of paternalistic domination." ${ }^{14}$ Barkin's sound warning echoes the conclusions reached by long-time Swedish labor activist Åke Wedin in his remarkable 1991 study entitled La "Solidaridad" Sindical Internacional y Sus Victimas (International Trade Unions' "Solidarity" and its Victims). Drawing on two decades of activity in the international trade union movement, this sensitive and self-aware labor intellectual offered a detailed and compelling self-criticism of European trade union programs in Latin America.

Recognizing the missteps, arrogance, and inadvertent consequences of even many well-intentioned initiatives, Wedin ends with a stimulating reflection on the nature of our goal of true labor solidarity, "a fundamental union principle with local, national, and international application." Recognizing its rarity, Wedin defines the ideal of solidarity as radically distinct from charity because it is based upon a relationship between equals. The practice of solidarity, he wrote, is:

... the common taking up of the responsibility for and defense of [workers'] common interests... Solidarity so conceived knows neither helpers nor helped, but rather equals who defend, as best they can, the common interest. One of those interests which they have in common, beyond the national frontiers, is to fortify the weak parts of the common world front of workers against employers. ${ }^{15}$

Dale Hathaway has grasped Wedin's challenge and advances us on the road to a different future. Yet these hopes will only be realized when militant and united struggle within each of our countries is combined with a new level of coordinated transnational action between the world's many national contingents of working and middle class peoples. A Luta Continua!

\footnotetext{
${ }^{14}$ Barkin, 3. See the fascinating discussion of the troubling power dynamics underlying international inter-union relations in the Argentine and Spanish airline industry offered by Hugo R. Perosa, Respuestas Sindicales a la Desregulación y Privatización de las Lineas Áreas: La Experiencia Latinoamericana, Latin American Labor Occasional Paper 12 (Miami: Center for Labor Research and Studies of Florida University, 1995).

${ }^{15}$ Ake Wedin, La "Solidaridad" Sindical Internacional y Sus Victimas (Stockholm: Instituto de Estudios Latinoamericanos de Estocolmo, 1991), 162. One chapter has been translated into English as International Trade Union "Solidarity" and its Victims, the Costa Rican Case, Vol. 43, Research Paper Series (Stockholm: Institute of Latin American Studies, 1986).
} 